Thushyanthan Baskaran

Mariana Lopes da Fonseca

\title{
Appointed Public Officials and Local Favoritism: Evidence from the German States
}

Max Planck Institute for Tax Law and Public Finance Working Paper 2017 - 09

December 2017

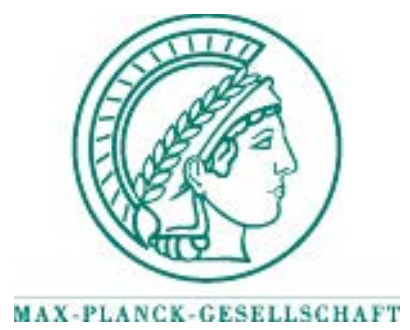

Max Planck Institute for Tax Law and Public Finance

Department of Business and Tax Law Department of Public Economics 
Working papers of the Max Planck Institute for Tax Law and Public Finance Research Paper Series serve to disseminate the research results of work in progress prior to publication to encourage the exchange of ideas and academic debate. Inclusion of a paper in the Research Paper Series does not constitute publication and should not limit publication in any other venue. The preprints published by the Max Planck Institute for Tax Law and Public Finance represent the views of the respective author(s) and not of the Institute as a whole. Copyright remains with the author(s).

Max Planck Institute for Tax Law and Public Finance

Marstallplatz 1

D-80539 Munich

Tel: $\quad+498924246-0$

Fax: $\quad+498924246-501$

E-mail:ssrn@tax.mpg.de

http://www.tax.mpg.de 


\title{
Appointed public officials and local favoritism:
}

\section{Evidence from the German states}

\author{
Thushyanthan Baskaran $^{\dagger *}$ Mariana Lopes da Fonseca ${ }^{\dagger \dagger}$ \\ ${ }^{\dagger}$ University of Siegen \\ ${ }^{\dagger \dagger}$ MPI Tax Law and Public Finance
}

\begin{abstract}
We study the local favoritism of appointed German state ministers. Matching hand-collected data on ministers' place of residence to a sample of more than 8,000 west German municipalities during the period 1994-2013, we find that the home municipality of a state minister experiences higher employment growth than control municipalities. Given the institutional context, this effect is ostensibly due to apolitical favoritism (home bias) rather than electoral considerations. We conclude that favoritism may lead to a distortion in the allocation of public resources even in contexts with strong political institutions.
\end{abstract}

Keywords: Distributive politics, Favoritism, Employment growth JEL codes: D73, H70

*Corresponding author: Thushyanthan Baskaran, Department of Economics, University of Siegen, Unteres Schloß 3, 57072 Siegen, Germany. Tel: +49(0)-271-740-3642. Email: baskaran@vwl.uni-siegen.de. 
"Politicians are the same everywhere."

Nikita Khrushchev

\section{Introduction}

In most countries, the public sector is responsible for the allocation of large amounts of economic resources. One of the potential perks of holding political office is thus the opportunity to leverage the influence that comes with the office to shape policy according to one's own preferences (Wittman, 1983). In this context, several authors suggest that the ultimate goal of public officials is not to further the common good but to pursue their own parochial interests (Besley, 2006). The literature identifies two distinct motivations that may drive such parochial political behavior. Politicians may want to get elected (re-election concerns) or they may just want to dispense favors to their "friends and families" (favoritism) (Cox and McCubbins, 1986; Franck and Rainer, 2012).

In general, empirical research on industrialized countries tends to focus on the re-election concerns of officeholders while research on developing countries emphasizes favoritism. The reason for this difference in focus may lie in the institutional context and the degree of electoral competition. In developed countries, the quality of institutions may prevent favoritism while electoral competition enforces the targeting of resources to politically important constituencies. In less developed countries, the absence of strong institutions may lead to a higher prevalence of (apolitical) favoritism.

Yet, is favoritism really absent in developed countries? If a desire to to help one's friends is a persistent cognitive trait of human beings, politicians may always engage in favoritism, irrespective 
of the institutional context in which they hold office. Strong institutions may limit blatant forms of favoritism, but rather than eradicating such behavior, they may induce politicians to be more surreptitious when dispensing favors. Against this background, we study the prevalence of favoritism using data from Germany, a democratic country with arguably strong institutions. Specifically, we explore whether German state ministers dispense benefits in the form of jobs to residents of their hometowns. Employment is an important concern of German citizens (Winkelmann, 2014). It is, more generally, also a suitable proxy for local economic development (Asher and Novosad, 2017).

The state tier in Germany is responsible for about $50 \%$ of all government spending and most of this spending is channeled through bureaucracies headed by the state ministers. Hence, state ministers are in a position to influence the allocation of significant amounts of public resources. At the same time, as we outline below, they have virtually no electoral incentives to target their home towns and its residents. To explore whether ministers nevertheless attempt to favor their hometowns, we combine data on employment growth over the period 1994-2013 with hand-collected data on the home municipality of state ministers for all (non-city) states in Western Germany. We explore whether employment growth in a municipality is higher when a resident joins the cabinet. Our identification strategy takes advantage of the fact that the treatment assignment mechanism, i.e., whether and when a resident is appointed as a minister, is arguably exogenous from the perspective of a given municipality. To check our identifying assumptions, we examine the spatial reach of the treatment effect and estimate placebo specifications.

We find that the timing of ministerial appointments coincides with a rise in the growth rate of employment. Treated municipalities experience a $0.4-0.5$ percentage point higher growth rate of 
employment per year than control municipalities. For a municipality of 10,000 inhabitants, this represents a disproportionate yearly increase in employment of about 40-50 employees. These findings suggest that state ministers facilitate hiring opportunities for co-residents. Given the lack of electoral incentives for state ministers, we interpret this rise in employment growth as evidence of favoritism. Further corroborating this interpretation is the fact that the growth in employment is limited to the minister's hometown. We observe no effects in neighboring municipalities nor on the county in which the minister's hometown is located (electoral districts typically span over several neighboring municipalities and take county borders into account).

To understand the means by which ministers induce the higher employment growth, we explore the allocation of intergovernmental grants and the development of various types of public sector employment within a municipality. We observe no hometown bias in the allocation of intergovernmental grants. We also find no effects on the number of local government employees, which further indicates that ministers do not allocate more fiscal resources to their hometowns (these would be typically channeled through municipal budgets which should hence lead to higher local government employment). However, besides fiscal resources such as grants, state ministers can also influence the distribution of employment opportunities for the state government. We indeed find that the number of state government employees increases significantly in the ministers' hometown once they assume office. This increase in state government employment explains about $25 \%$ of the entire employment growth in the hometown.

The remaining part of the observed employment growth is ostensibly due to an increase in private sector employment. While it is difficult to explore how ministers generate additional private 
sector employment, several pieces of evidence suggest that they use their personal connections to uncover employment opportunities for residents of their hometowns. First, specifications that link employment growth to the post-office careers of ministers indicate that state ministers who continue in politics, transition to positions in public administration, or move to the business sector, have a stronger effect on employment growth than politicians that enter associations (often to head up non-profit interest groups) or academia. It is plausible that continued political influence as well as connections in the business sector or in public administration beget more tangible benefits than connections in the non-profit sector and in academia. Second, we find that prime ministers have a substantially larger effect on employment growth that other ministries. The prime minister does not (directly) control a large budget and hence her effect on employment growth is unlikely to come from a increased allocation of fiscal resources. But prime ministers are the most influential politicians of their state and, as such, it is likely that they have useful connections that they can draw upon to help residents in their hometowns.

In sum, we make three main contributions to the literature. First, our emphasis on favoritism implies a new explanation for geographical distortions in the allocation of public resources in industrialized countries. Existing research from industrialized countries typically interprets geographical distortions in light of the standard neoclassical model of politics as transfers directed to a subset of the electorate for the purpose of re-election (Weingast et al., 1981; Cox and McCubbins, 1986; Cox, 2009). Two partial exceptions are Carozzi and Repetto (2016) and Fiva and Halse (2016). Carozzi and Repetto (2016) find a birth town bias in the allocation of central government transfers driven by Italian members of parliament who were not born within their electoral 
district. However, despite the absence of a direct electoral motive, the authors nonetheless argue that electoral incentives may be at work. By increasing transfers to their hometowns, members of parliament seem to lay the groundwork for a subsequent career in local politics. Similarly, Fiva and Halse (2016) identify a hometown bias in public road construction by regional governments in Norway. Since members of regional councils are elected in an at-large proportional electoral system, there is no electoral reason for a council member to target her hometown. The explanation that these authors offer is that council members are recruited from local politics and appear to remain loyal to their political roots.

In our setting, state ministers are not elected but appointed (in effect by the prime minister in conjunction with the leadership of the parties in power). Accordingly, in line with the above studies they have no immediate electoral concerns. However, in addition, state ministers generally do not pursue a career in local politics after their tenure in the cabinet, which implies that there are no post-office electoral incentives at work. Similarly, they also do not have strong roots in local politics - state ministers are not recruited from the pool of local council members or mayors. They thus have no local political loyalties to serve, either.

Second, our findings add to previous empirical research on regional (or ethnic) favoritism. Burgess et al. (2015) show that democracy can limit the geographical distortion in public resources. In contrast, we find that public officials aim to dispense favors to co-residents even in contexts with strong democratic institutions. Our results are therefore in line with studies such as Hodler and Raschky (2014), Franck and Rainer (2012), and Kramon and Posner (2016) which show that an (ethnic) home bias can be present both in autocratic and (partially) democratic settings. 
Third, we further contribute to various strands of the political economy literature. For example, a large literature discusses the differences in policy choices between appointed and elected officials. The results in this literature indicate that elected public officials may have an incentive to distort policies for electoral reasons (Rogoff, 1990; Hessami, 2017). We show that appointed politicians may also cause economic distortions despite the absence of electoral incentives. Furthermore, our paper is related to the literature on the political determinants of local economic development. Asher and Novosad (2017), for example, find that in India, employment growth is higher in constituencies aligned with the state government. Our results suggest that hometown favoritism may be an alternative political determinant for local development. This paper is also related to the political economy literature on the allocation of intergovernmental grants in decentralized countries. For example, Brollo and Nannicini (2012) find that the Brazilian federal government allocates more transfers to municipalities headed by politically aligned mayors. Adding to this literature, we show that in the absence of electoral incentives, politicians may well not distort intergovernmental grants but might rather rely on public sector employment or their personal connections to potential employers in the private sector to dispense favors. Finally, this paper is related to the literature on the economic value of personal political connections. Acemoglu et al. (2016), for example, show that firms connected to Timothy Geithner experienced abnormally high stock market returns on the day that his nomination as US Treasury Secretary was announced. Our results suggest that personal connections to politicians may not only benefit business leaders and other members of the elite, but can also engender tangible, even if more modest, benefits for regular people. 


\section{Background}

\subsection{State politics in Germany}

The Federal Republic of Germany consists of 16 states. Ten states are in the former west and six in the former east Germany $!^{1}$ Three large cities are states in their own right and are called city-states (Berlin, Bremen, and Hamburg). These states have no subordinate municipalities.

All states are parliamentary democracies and have a separate elected government. Voting rules vary across states, but all use some variant of proportional representation (PR). Specifically, in most states, the electoral rule follows a mixed-member PR system - also know as personalized PR (personalisiertes Verhaeltniswahlrecht) - that awards a seat to individual candidates in first-pastthe-post elections while ensuring that the seat share of each party in the state parliament matches its vote share across the entire state.$^{2}$ Hence, the number of votes that a party receives in the PR vote is decisive for the final distribution of seats in the legislature.

The state parliament elects a state cabinet, its executive counterpart for the entire legislative period, with a legislative term generally lasting five years in most states.$^{3}$ Every cabinet requires

\footnotetext{
${ }^{1}$ The city-state of Berlin was divided between east and west before reunification. Given its location in the east, we count it as an eastern state.

2 Typically, voters have two votes: the "first vote" is used to elect a candidate in a single-member constituency, and the "second vote" is used to vote for a party list. The total number of seats to which a party is entitled depends on the distribution of "second votes". All candidates who won in their districts receive a seat, and candidates from the party lists fill any remaining seats. Exceptions to this rule are the states of Baden-Württemberg and Saarland and the city-states of Hamburg and Bremen. For more details on the electoral rules for state parliaments in Germany see http://www.wahlrecht.de/landtage/index.htm (in German).

3 The only exception is the city-state of Bremen which has a four-year parliamentary term.
} 
the support of at least $50 \%$ of the members of parliament (MPs). In practice, either a single party wins more than $50 \%$ of the seats in the parliament and can thus form the cabinet by itself or several parties, which jointly surpass the $50 \%$ threshold, agree to form a coalition cabinet.

In both cases, internal party politics determine how key positions in the cabinet are staffed. In particular, who gets appointed to what ministry is under the purview of the prime minister and the party leadership. Ministerial appointments do not depend on how politicians perform in their districts, i. e., in the first-past-the-post election, nor on how the party performs in their municipality or region. Instead, the personal prominence of politicians in a state, their expertise, and connections to the party leadership are the decisive factors. Often ministers do not even run in the first-pastthe-post elections, nor do they have to be MPs.

The structure of state cabinets, notably the size of the cabinet, varies across states and over time; each state government determines the structure at its discretion. Cabinet size typically ranges from 10 to 20 ministers. Each minister is responsible for many distinct policy areas. Which ministry is responsible for which policy area also varies across states and over time. Still, each state cabinet has certain core ministers, typically staffed by relatively prominent state politicians, and several further ministries with varying denominations. The core ministers are the prime minister, the finance minister, and the interior minister.

The prime minister is the most powerful member of the cabinet and is usually the most prominent politician of her party within the state. Her power originates from a number of institutional rules. Notably, in most states, the prime minister is the only member of the cabinet who is directly elected by the state parliament. Once confirmed by the parliament, she typically appoints the remaining 
members of the cabinet. Depending on the state, the appointments may or may not be subject to parliamentary approval. Cabinets cannot reach decisions that the prime minister opposes and she is answerable only to the parliament. However, the need to maintain a parliamentary majority implies that despite her institutional power, she is still subject to various political restrictions. In particular, she has to ensure that she retains the support of her party (and of the other relevant parties in the case of coalition governments).

The second core ministry is the finance ministry. Finance ministers ultimately control the budgets of all other ministries. In particular, no expenditure can be undertaken if the finance minister objects. This power over the budget gives finance ministers substantial influence within the cabinet. The third core position is held by the interior minister, who traditionally also has a prominent position in the cabinet. Interior ministers directly control a large administration since the responsibility for policing is under the purview of the states in German federalism. Moreover, interior ministers are also responsible for supervising local governments, which gives them added visibility in the state and importance in the cabinet.

The other ministries cover a broad range of policy areas such as education and culture, economy and infrastructure, social policy and health, and environmental issues. The precise delineations of policy areas and corresponding denominations vary across states. Thus, the budgets of individual ministries cannot be compared across states or over time. However, the Federal Statistical Office offers harmonized expenditure data for specific policy areas. According to these data, the most important policy areas for state cabinets are education, culture, and science (around 30\%-35\% of total state expenditure), social policy and health (around 10\%-15\%), and economic promotion and 
infrastructure (around 5\%-10\%). State ministers generally wield influence over the allocation of substantial financial resources given the extensive expenditure decentralization in Germany; the state tier in Germany accounts for approximately $50 \%$ of total public spending.

\subsection{Theoretical Considerations}

A large literature studies how political considerations determine the geographical allocation of public resources. Two main theoretical explanations are typically put forward for such political biases. First, and according to Weingast et al. (1981), this bias is due to the geographical basis of political constituencies. Different models predict that in an attempt to increase their probability of re-election politicians target different constituencies, from their core supporters (Cox and McCubbins, 1986), to swing voters (Lindbeck and Weibull, 1987), or special interest groups (Myerson, 1993; Coate and Morris, 1995). Such targeting may create geographic patterns in the distribution of public resources.

Empirical studies usually focus on the distribution bias toward core supporters by exploring alignment effects in distributive policies. Many authors show that subnational units belonging to the ruling party tend to receive higher federal outlays, e.g., higher discretionary transfers for infrastructure in Brazil (Brollo and Nannicini, 2012), larger federal grants for transport and defense spending in the US (Albouy, 2013) and a higher allocation of EU Structural and Cohesion Funds in Hungary (Murakozy and Telegdy, 2016). Johansson (2003), on the other hand, provides evidence municipalities with a large number of swing voters being targeted using a panel data of 225 municipalities in Sweden over the years 1981-1995. Alternatively, Cascio and Washington (2014) 
examine evidence of the targeting of special interest groups in their study of the enfranchisement of black communities in the south of the US following the Voting Rights Act of 1965.

Yet, electorally motivated favoritism is an unlikely reason for German state ministers to favor their home municipalities. Targeting specific areas is not an effective electoral strategy within the context of an essentially PR system (Lizzeri and Persico, 2001; Milesi-Ferretti et al., 2002). Moreover, individual ministers do not have to be successful or even have to run in the first-pastthe-post-election, thus they do not need to cultivate a "personal vote". Even if state governments decide to target specific constituencies, there are no electoral incentives to concentrate pork in the municipalities of state ministers as the first-past-the-post constituencies typically cover several municipalities - any votes gained in any single municipality will ultimately have a negligible effect on the outcome within a constituency.

The second, and in our context more relevant theoretical mechanism, comes from models of identity politics. Rather than political considerations, politicians may favor their hometowns for personal reasons. There is a well-established literature demonstrating that the identity of politicians affects the allocation of public resources. Politicians typically favor members of their own group identity, which has been proxied in the literature by gender (Chattopadhyay and Duflo, 2004), castes and tribes (Pande, 2003), or ethnicity (Franck and Rainer, 2012). Anecdotal evidence of regional favoritism exists for many developing and emerging countries. Do et al. (2016) and Besley et al. (2011) provide systematic evidence of this phenomenon for Vietnam and India, respectively. In these contributions, geographical biases are not explained by the leaders' political calculus, but 
by an innate preference for helping their hometowns. This preference is also the most plausible explanation for the politically motivated distortion of public resources in German states.

Even though this mechanism is more often associated with weak institutional settings, Hodler and Raschky (2014) show, using a sample of 126 countries and over 38,000 regions, that regional favoritism is widespread. Similarly, Franck and Rainer (2012) find for a sample of 18 African countries that ethnic favoritism is equally present in democracies and autocracies. Burgess et al. (2015) and Kramon and Posner (2016) in turn, using Kenya as a case study, show that visible forms of favoritism, such as increases in infrastructure investment, cease in periods of democracy, but more subtle forms, such as the supply of extra inputs in the education sector, persist. These findings suggest that the difference between countries with strong and weak institutions might not lie in the prevalence of favoritism but in its visibility.

\section{Data and methodology}

\subsection{Data}

We rely on hand-collected data on the composition of German state cabinets in the eight west German non-city states from 1994 to 2013. Using various sources (particularly internet searches and bibliographical databases), we were able to collect information on the place of residence of 298 of the 367 state ministers who were in office in the eight states during the period 1994-2013 (about $81 \%) 4_{4}^{4}$ We add to this data information on the municipalities where ministers went to school, the

\footnotetext{
${ }^{4}$ We identify ministers during the early sample period using information provided by Schnapp (2006). For more recent years, we rely on information available from official state government or state parliament websites.
} 
specific ministries headed, the entry and exit dates into and out of office, and further characteristics of the ministers.

Panel A of Table 1 reports basic summary statistics on the characteristics of ministerial appointees. The average minister enters a cabinet at about age 49 and stays in office for roughly eight years. Around $29 \%$ of the ministers are female. Regarding their political affiliation, the majority of the ministerial appointees are either from the CDU (28\%) or SPD (43\%). For the ministers for which we have information on the career path following the dismissal from office, about 53\% remain in politics, while $22 \%$ pursue careers in the private sector and $10 \%$ represent the interests of different associations. About $24 \%$ of the ministers for whom we have data on both places of residence and of schooling continue to live in the town where they went to school.

Our primary outcome variable is the annual growth rate of social-security covered employees that reside in a municipality: 5 defined as follows:

$$
y_{i, t}=\Delta \log (\text { employment })_{i, t}=\log (\text { employment })_{i, t}-\log (\text { employment })_{i, t-1} \text {. }
$$

Social-security covered employment data are available from the German Employment Agency from 1993 onward. Even though social-security covered employment does not include the entire universe of employment, it allows us to assess the employment prospects of most of the workingage population as it is the default form of work in Germany. The majority of private and public

\footnotetext{
${ }^{5}$ Note that we thus focus on employment according to the residence principle (Wohnortprinzip), i.e., the number of employees residing in a municipality wherever they may actually work. We explore employment according to the workplace principle, i.e., the number of employees working in a municipality wherever they may actually live, in section 5.3
} 
sector employees belong to this category. The main groups that are outside of this category are the self-employed and certain types of public servants. While conditions and wages of social-security covered jobs vary, they come with many benefits. Among them the fact that they award relatively high job security, especially in the public sector.

While Germany has 16 states and about 11,000 municipalities, we make two sample restrictions. First, we drop municipalities located in the former east German states. Municipalities in the former east Germany were subject to various boundary reforms, which makes it difficult to track a sufficient number of municipalities over time. Moreover, the former east German states were hit by various idiosyncratic employment shocks, such as the transition from the socialist to the market economy in the early Nineties, and massive outmigration. Second, we drop the three city states given that they have no subordinate municipalities. Panel B of Table 1 reports summary statistics on municipalities, including the growth rate of employment. On average, the municipal-level annual employment growth in Germany during the sample period is about $0.6 \%$.

We use the data on state ministers and the data on employment to create a municipal-level dataset for the period 1994-2013. Specifically, we use the available information on the place of residence of a state minister and the entry date to the cabinet to generate a dummy variable that turns to one for a given municipality in the year a resident is appointed state minister (until the end of the sample period). More formally, let Minister $_{i, t}$ be the dummy variable indicating treatment, where $i$ indexes municipalities and $t$ time. For each municipality $i$, treatment occurs if during year $t$ a resident is appointed state minister. The Minister $_{i, t}$ is then equal to one for every year after the appointment. 
Overall, our sample covers 8,362 municipalities. The total number of municipalities in western Germany in 2013 was $8,459 \sqrt[6]{6}$ Figure 1 shows a map that indicates all included municipalities. Altogether, there are 184 municipalities that at some point during the sample period were the residence of a minister. We refer to these municipalities in the following as "minister municipalities". Panel B of Table 1 shows that of the 167,240 municipality-year pairs in the dataset, around $1.4 \%$ (2,314 observations) assume the value one, i.e., are the residence of a minister.

We collect additional data to understand how ministers affect employment growth in their home municipality. First, we use data on investment grants paid by the state government to municipalities. Investment grants are the largest discretionary transfer program in Germany and the most obvious fiscal channel through which ministers may try to favor their home municipalities. Data on investment grants is available from the Federal Statistical Office for all German municipalities, albeit only for the period 2008-2013. Second, we use data on public employment available from the different state statistical offices in order to test whether the changes in social-security covered employment are the result of additional employment opportunities in the public sector.

\subsection{Empirical strategy}

We study whether employment growth in a municipality increases when a resident is appointed to the state cabinet. For this purpose, we estimate the following general difference-in-differences (diff-in-diff) regression model:

\footnotetext{
${ }^{6}$ Some municipalities may lack data on employment for some years either due to boundary reforms or because of generic missing data and are therefore dropped from the sample.
} 


$$
y_{i, t}=\alpha_{i}+\gamma_{t}+\beta \text { Minister }_{i, t}+\varepsilon_{i, t},
$$

where $y_{i, t}$ is the annual growth rate of social security covered employment in a municipality as defined in equation (1) and Minister is the dummy variable indicating whether a municipality is the place of residence of at least one minister. Since we have a panel of municipalities, we follow Islam (1995) and control for municipality fixed effects $\left(\alpha_{i}\right)$ to account for municipality-specific factors that may lead to persistently higher or lower employment growth rates. In addition, we control for common shocks $\left(\gamma_{t}\right)$ using various strategies: by including year fixed effects, statespecific trends, and state-specific year fixed effects. Standard errors are clustered at the municipal level and are robust to heteroscedasticity.

Two assumptions must hold for $\hat{\beta}$ to retrieve a causal effect. First, there must be no municipalitylevel omitted variables correlated with the timing of the ministerial appointment. Second, there must be no reverse causality between employment growth in a minister municipality and the propensity of a resident to be appointed to office. We validate both assumptions in robustness checks. However, they are plausible in our setting. As discussed, political careers at the state-level and, in particular, ministerial appointments are independent of municipality-level developments given the institutional details of German state politics. To advance at the state-level, politicians have to gain the support of party elites from across the state. Though party elites may factor in from which geographical region a minister originates, the specific municipality in which she resides is unimportant. Moreover, while implicit regional quotas for ministerial appointments may 
exist, their relevance does not change over time. Finally, the party of a minister has to actually be part of the ruling coalition after a state-election, which is, in general, an uncertain event.

\section{Results}

\subsection{Baseline results}

We collect the baseline results in Table 2, All models include municipality fixed effects and rely on heteroscedasticity- and cluster-robust standard errors. Model (1) uses simple year fixed effects to account for common shocks. Model (2) additionally controls for state-specific trends. Model (3) replaces the year fixed effects and state-specific trends with state-specific year fixed effects. ${ }^{7}$

We find that the minister dummy is positive and significant ( $\mathrm{p}$-value $=0.000)$ in all models. Coefficient estimates indicate that the growth rate of employment is, on average, higher in minister relative to control municipalities. The magnitude of the coefficients suggests a $0.4-0.5$ percentage point significantly higher growth rate of social security covered employment in minister municipalities. For a municipality with 10,000 inhabitants, this estimate implies that employment growth is, on average, higher by 40-50 individuals in minister municipalities annually.

\footnotetext{
${ }^{7}$ Including state-specific fixed effects consists of the most conservative version of equation (2). State-specific fixed effects subsume the year fixed effects and state-specific trends.
} 


\subsection{Robustness tests}

\subsubsection{Different Specifications}

In Table 3, we collect various robustness tests that explore the sensitivity of the results to different samples and specifications. All models include municipality and state-specific year fixed effects, and rely on heteroscedasticity- and cluster-robust standard errors.

The first robustness check, in model (1), tests whether results are robust to the definition of the dependent variable. Instead of the growth rate of employment, we use the annual change in the level of employment as the dependent variable. The result is consistent with the baseline estimates; the average growth in the level of employment in a minister municipality is positive and significant at around 263 individuals.

Models (2), (3), and (4) test the robustness of the results to the various sample adjustments. Model (2) excludes very small municipalities, i.e., that had on average less than 500 social-security covered employees during the sample period. Given their small size, relatively minor variations in the absolute number of employees may result in large growth rates. Model (3) excludes state capitals. They have been almost continuously the place of residence of at least one minister and may not be, more generally, comparable to regular municipalities. Model (4) excludes observations with employment growth rates below the 1st and above the 99th percentile (some of these are extreme outliers and likely include data entry errors). Coefficient estimates remain in line with the baseline results indicating a $0.4-0.5$ percentage point higher growth rate of employment in minister municipalities. 
Finally, models (5) and (6) test the spatial reach of the treatment effect. Model (5) controls for a dummy variable that identifies the municipalities belonging to the same county as the minister municipalities (the dummy is zero for the minister municipality but one for all other municipalities in the same county). Model (6) controls for a dummy that is one for all municipalities that are contiguous to minister municipalities. Both robustness checks allow us to test whether we identify an at-large or targeted treatment effect. The insignificance of the coefficient estimates indicates that the increase in the growth rate of employment is restricted to minister municipalities. These results have two distinct implications. First, they show that we observe an effect that is directly targeted at the residents of the ministers' hometown. They hence rule out that spatially correlated shocks are responsible for the baseline findings. Second, they indicate that electoral incentives are not responsible for why ministers target their hometowns. If a minister dispensed favors for electoral reasons, such favors should also be directed to neighboring municipalities, given the layout of electoral districts.

\subsubsection{Omitted Variables}

To further address concerns regarding omitted variable bias, we restrict the sample to minister municipalities and their immediate neighbors. A municipality is considered a neighbor of a minister municipality when its centroid lies within a fixed distance from the centroid of a minister municipality. We use four thresholds for the critical distance: $50 \mathrm{~km}, 40 \mathrm{~km}, 30 \mathrm{~km}$, and $20 \mathrm{~km}$. We also create variables that capture neighborhood-specific trends, i.e., a separate trend variable for each minister municipality and all municipalities located in its neighborhood. Restricting the sample to immediate neighbors and controlling for neighborhood-specific trends accounts for regional trends 
that may jointly determine employment growth and the propensity of a politician from that region to be appointed to office..$^{8}$

We collect the results in Table 4. As indicated, all models control for state-specific year fixed effects, municipality (and hence neighborhood) fixed effects, and neighborhood-specific trend. We find that the coefficient estimates are positive and significant, and vary between $0.3-0.4$. These results are in line with the baseline estimates and show that a minister municipality significantly benefits from the ministerial appointment even compared to its immediate neighbors.

\subsubsection{Measurement error}

When we cannot find information on the place of residence of ministers during their tenure, we rely on their current residence. To address issues of measurement error that can result from this approach, we collect information on the school-town of ministers. We hypothesize that ministers whose current place of residence is the same as the municipality where they went to school also lived in that municipality when they were in office. We thus estimate models where we distinguish between ministers who still live in the municipality where they went to school and ministers who no longer live in the same municipality or for whom we do not have information on the place of schooling.

We collect the results in Table 5. Model (1) includes the dummy indicating municipalities that are both the place of schooling and the (current) residence of a minister. Model (2) includes

\footnotetext{
${ }^{8}$ As models (5) and (6) in Table 3 , the results also allow us to assess whether ministers target their home municipality or the surrounding broader region - and in particular the electoral district. If ministers target larger regions, the coefficient estimate of the Minister dummy should approximate zero once we limit the sample to the immediate neighborhood of a minister municipality.
} 
the dummy indicating municipalities that are the residence of a minister but not their place of schooling or for whom we do not have information on the place of schooling. Model (3) includes both dummy variables.

Coefficient estimates are positive, significant, and in line with previous estimates across the different models. Model (3), where we include both dummy variables, suggests that the growth rate of employment is slightly higher in magnitude for municipalities that are both the residence and place of schooling of a minister. However, based on (un-reported) t-tests we cannot assert that both estimates are significantly different. These results show that potential measurement error has no significant effect on the baseline estimates.

\subsubsection{Reverse causality}

To explore whether our results are driven by reverse causality, we re-run equation (2) using placebo appointment years. If employment growth in a municipality increases the likelihood of a resident becoming a state minister, we should observe higher growth rates even in the pre-appointment period. We therefore create fake treatment dummy variables indicating one, three, and five years before the ministerial appointments.

We collect the results in Table 6, In models (1)-(3), we test each of the placebo dummy variables. In models (4)-(6), we replicate the regressions but also include our true treatment variable. All specifications include municipality and state-specific year fixed effects, and rely on heteroscedasticity- and cluster-robust standard errors. In models (1)-(3), the placebo coefficient for the year preceding ministerial appointments is statistically insignificant while the placebo treatments corresponding to three and five years before the appointments are significantly negative. The 
negative coefficient ostensibly captures the fact that employment growth in the years immediately before the appointment was lower than in the post-appointment period, indicating that reverse causality is not responsible for our baseline results. This conclusion is further confirmed by models (4)-(6). When we add the treatment dummy, the placebo dummy variables are consistently insignificant.

\section{Extensions}

\subsection{Timing}

The longer a minister has been in office, the stronger the effect should be on employment growth. Any formal policy measures adopted to benefit a hometown should need some time to take effect. Moreover, their personal influence will likely grow with their time in office. To study the precise timing of the treatment effects, we analyze the temporal pattern of employment growth during ministerial appointments and after the dismissal of appointees. We divide the tenure of ministers into the different periods in office and create dummy variables for the years after the dismissal of the ministers.

We collect the coefficient estimates in Table 7. Model (1) focuses on the full tenure of the ministers and the period after dismissal from office; both coefficient estimates are positive and significant. These results suggest that the benefits from being a minister municipality increases in the number of years the minister is in office. Moreover, the results show that there is no reversal in employment after a minister's dismissal from office. Not only do the jobs created during the 
tenure of ministers appear to persist into the post-office period, but new jobs are even added. This particular result indicates that it is the personal connections that ministers may have gained during their time in office that are particularly beneficial for employment growth in their home towns.

Likewise, models (3) and (4) provide the same insights. In model (3) we divide the tenure of the ministers into five years in office and all years thereafter. In model (4), we divide the tenure into the first three years in office, years four to five, six to 10, and all years after until dismissal and postdismissal. All coefficient estimates show a positive and significant treatment effect in both models. Model (3) and (4) show that the growth rate of employment in a minister municipality increases during the minister's tenure. While the minister is in office, the growth rate of employment is $0.3-$ 0.8 percentage points higher in minister municipalities. After the dismissal from office, the growth rate of employment remains about 0.8 percentage points higher.

\subsection{Public Employment}

The rate of employment growth increases significantly in a municipality upon the appointment of a resident to the state cabinet. However, how ministers promote this growth in employment remains unclear. In general, ministers have several means of creating employment opportunities for the residents in their municipalities. First, they can provide additional financial transfers to their hometowns. Most ministries run discretionary grant programs to which municipalities can submit projects for funding. Ministers may ensure that applications from their municipalities are treated more favorably by the administration. Second, ministers can treat their home municipalities favorably in the distribution of public projects, such as road construction, cultural venues, or other 
infrastructure projects. Finally, ministers can use their influence to directly obtain jobs for coresidents. They can put pressure on public agencies that are directly subordinate to them to hire co-residents or they can provide informal recommendations to private sector firms or public sector employers. They can also ask fellow ministerial colleagues for favors.

To explore the underlying mechanism, we study data on the growth rate of public employment at different levels, and examine the growth rate of investment grants to municipalities. We collect the results in Table 8 . As before, all models include municipality and state-specific year fixed effects, and rely on heteroscedasticity- and cluster-robust standard errors. Models (1) through (6) study the growth rate of state employment, local government employment, special purpose organization employment - e.g., employment in organizations set up by a collective of municipalities employment in social security services, and in legally independent state and local organizations in minister municipalities, respectively. The dependent variable in model (7), in turn, is the growth rate of state investment grants received by a given municipality.

The results show a positive and significant $(\mathrm{p}=0.002)$ effect of ministerial appointments on the growth rate of state employment. Having a resident appointed to the state cabinet increases state public employment in the municipality by around 1 percentage point. The coefficient estimate for the effect of ministerial appointment on the growth rate of employment in social security services is also positive and significant $(\mathrm{p}=0.068)$ with a magnitude of about 6 percentage points. We find no effect of ministerial appointments on the remaining forms of public employment. In particular, being a minister municipality does not lead to more local government employees. Similarly, we 
find no effect on the growth rate of investment grants. The latter two findings indicate that ministers do not facilitate employment growth by allocating more fiscal resources to their home municipality.

To estimate how the effect of ministerial appointments on employment growth works through state-level public employment, we calculate the local average treatment effects at the mean. Backof-the-envelope calculations show that social-security covered employment grows by 9.88 persons per year while average state public employment increases by 2.46 and employment in social security services by 0.8 persons. Thus, state public employment and employment in social security services explain about $25 \%$ and $8 \%$ of the growth in social-security covered employment in minister municipalities.

\subsection{Place of employment}

Some municipalities are industrial or administrative centers while others effectively serve as suburbs or are generic rural towns. Consequently, it may not be possible for ministers to generate suitable employment opportunities for residents within their own municipality. This fact is the reason why we focus on the growth rate of employees among the residents of a municipality as our main outcome (wherever a job may actually be located). This is not identical to the growth rate of employees working in that municipality (wherever an employee actually lives).

In Table 9, we relate the growth rate of employees working in a municipality to the minister dummy. While we observe positive coefficient estimates, they are substantially smaller than in the baseline regressions and are insignificant. Consistent with the previous results, these estimates indicate that ministers do not primarily use fiscal transfers or even state-level employment to generate 
employment opportunities. Such strategies would result in an increase in the number of employees working within a municipality. Instead, they mostly appear to use their influence and connections to match residents with employers in other towns.

\subsection{Heterogeneous Effects}

In this section, we explore how different characteristics of ministers affect the growth rate of employment. Specifically, we test for heterogeneous effects depending on the ministry department and the post-office career path to understand the circumstances under which ministers promote employment growth in their home municipalities. We also test for heterogeneous effects according to the partisan affiliation and gender.

\subsubsection{Policy area}

Some ministerial portfolios may offer more opportunities to dispense favors than others. Portfolios with large budgets typically have substantial bureaucracies and oversee a correspondingly large workforce. Accordingly, ministers with such portfolios may be in a better position to generate employment for the residents in their hometown. On the other hand, ministers who are higher up in the political ladder, such as the prime minister, finance minister, or interior minister, may be more effective because they have more valuable connections, particularly to private sector firms.

We hence estimate separate treatment effects for different types of ministers. As ministries are not standardized across states and differ in the delineations of policy areas we classify them (using their official denominations) into seven main categories: prime minister, finance minister, interior minister, ministries dealing with economy and infrastructure, ministries dealing with social policy 
and health, those dealing with culture and education, and ministries dealing with environmental protection.

We collect the results in Table 10 . There, we find a large positive and significant effect for the prime-minister, followed by the ministries for economy and infrastructure, and social policy and health. Coefficient estimates are also positive and significant, albeit to a smaller degree, for the ministries of culture and education and environmental protection.

The ministries for economy and infrastructure, social policy and health, and culture and education tend to be responsible for a large budget and a high number of public sector jobs. Overall, these results indicate that ministries that come with direct leverage are beneficial for a municipality. A notable exception is the prime minister. The prime minister does not have a large budget and is not directly responsible for many jobs. Thus, presumably it is the prominence of prime ministers and their personal influence that leads to higher employment growth in their home municipality.

\subsubsection{Post-office careers}

The previous results show that ministers continue to have a positive impact on employment growth even after they leave office. One reason for this continued effect may be that decisions made while in office have persistent implications for how employment evolves in a minister's hometown. Another possibility is that ministers leverage their connections during their post-office career to help their co-residents. If this is the case, it seems plausible that some post-office careers are more beneficial then others for co-residents.

Hence, we gather data on the career path of ministers after their tenure in the state cabinet. We have this information for around $70 \%$ of the ministers in our sample. To study whether the post- 
office career path has an influence on the growth rate of social security employment in a minister municipality, we re-estimate equation (2) while including a dummy variable for minister municipalities during the post-office period interacted with each of the following post-office occupations: a political career, a career in public administration, in the private sector, as a member of an association, and in academia.

A career in politics typically implies that ministers are repeatedly appointed to the state cabinet (when a new cabinet is formed) or become federal MPs. Careers in the public administration often entail being the chairman or council member of a public agency. Ministers pursuing careers in the business sector often practice law or become consultants. Other ministers are involved with associations (often as heads of non-profits) or continue with a prior academic career.

In Table 11, we collect the different coefficient estimates. We find a positive and significant post-office effect in the range of $0.5-0.7$ percentage points for ministers who forge a career in politics, in public administration, and in the private sector. In contrast, we observe no significant post-office effect for ministers who transition into associations or academia. These findings show that there is significant heterogeneity in how post-office careers affect employment growth once a minister leaves office. They suggest, furthermore, that one important channel through which ministers influence employment growth is their personal connections to potential employers, which are arguably stronger in, for example, the business sector than in academia.

\subsubsection{Ideology}

Ministers have different partisan affiliations. As shown in Panel A of Table 1 around $70 \%$ of ministers belong to one of the two biggest parties, CDU or SPD. Around $8 \%$ of ministers are 
from the FDP and 7\% from the Green Party with the remaining 13\% belonging to other smaller parties. It is possible that ministers of certain parties are less able or willing to engage in hometown favoritism than others. We hence test for heterogeneity across parties by interacting the minister dummy with dummies for the partisan affiliation of a minister. The results are shown in Table 12. We find that the coefficient estimates are positive and significant for the ministers from the four main parties in Germany. Ministers from all parties hence engage in favoritism. We also find in (unreported) t-tests that there are no significant differences across parties in the extent of favoritism.

\subsubsection{Gender}

Another important dimension in how ministers differ is, of course, their gender, with a female representation of about $29 \%$. Several studies indicate that there are significant differences in policy choices and in the degree of opportunistic behavior between men and women (Duflo, 2012, Brollo and Troiano, 2016). We hence explore whether the degree of favoritism differs between male and female ministers by interacting the minister dummy with a dummy for gender. We collect the results in Table 13. We find that the coefficient estimates are positive, significant, and in line with the baseline estimates for both genders. Both men and women hence appear to engage in favoritism. Moreover, the extent of favoritism does not seem to differ either: the estimates are not statistically different from each other as suggested by (un-reported) t-tests. 


\section{Conclusion}

We study local favoritism by appointed government officials in Germany using hand-collected data on members of state cabinets in the west German states. Relying on a sample of more than 8,000 municipalities during the period 1994-2013, we find that the home municipalities of state ministers experience higher growth rates of social security covered employment than control municipalities.

Given the institutional features of state politics in Germany, we can assert that this effect is driven by apolitical favoritism rather than electoral considerations. In extensions, we provide evidence indicating that the increase in employment is partially achieved through the mediation of state-level public sector job opportunities rather than through the targeted redistribution of pork. Moreover, the effect is stronger for ministers in control of policy areas with large budgets and for ministers who continue in politics or pursue a career in public administration or the private sector after their tenure in office. We also find that the effect does not differ across parties nor between genders.

Overall, these findings indicate that state ministers engage in favoritism, leveraging their influence and bureaucracies to create employment opportunities for co-residents. This paper hence adds to the recent literature showing regional favoritism to be widespread. It also shows that while strong democratic institutions can prevent visible forms of geographical targeting, more subtle mechanisms remain available to officeholders. Nevertheless, it seems that the welfare implications of the favoritism are relatively mild in our context. While we observe some geographical distortions in state government employment, ministers appear to mostly use their personal connections to uncover employment opportunities for residents of their hometowns. If this merely involves "putting in a good word" for co-residents, the social costs are presumably relatively small, even 
if such forms of favoritism may imply that less well-connected but potentially better qualified candidates are crowded out.

\section{References}

Acemoglu, D., S. Johnson, A. Kermani, and J. Kwak (2016). The value of connections in turbulent times: Evidence from the United States. Journal of Financial Economics 121, 368-391.

Albouy, D. (2013). Partisan representation in congress and the geographic distribution of federal funds. Review of Economics and Statistics 95(1), 127-141.

Asher, S. and P. Novosad (2017). Politics and local economic growth: Evidence from India. American Economic Journal: Applied Economics 9(1), 229-273.

Besley, T. (2006). Principled Agents? The political economy of good government. Oxford: Oxford University Press.

Besley, T., R. Pande, and V. Rao (2011). Just rewards? Local politics and public resource allocation in south India. The Wrold Bank Economic Review 26(2), 191-216.

Brollo, F. and T. Nannicini (2012). Tying your enemy's hands in close races: The politics of federal transfers in Brazil. American Political Science Review 106, 742-761.

Brollo, F. and U. Troiano (2016). What happens when a woman wins an election? Evidence from close races in brazil. Journal of Development Economics 122, 28-45. 
Burgess, R., R. Jedwab, E. Miguel, A. Morjaria, and G. Padró i Miquel (2015). The value of democracy: Evidence from road building in Kenya. American Economic Review 105(6), 18171851.

Carozzi, F. and L. Repetto (2016). Sending the pork home: Birth town bias in transfers to Italian municipalities. Journal of Public Economics 134, 42-52.

Cascio, E. U. and E. Washington (2014). Valuing the vote: The redistribution of voting rights and state funds following the voting rights act of 1965. Quarterly Journal of Economics 129(1), $379-433$.

Chattopadhyay, R. and E. Duflo (2004). Women as policy makers: Evidence from a randomized policy experiment in India. Econometrica 72(5), 1049-1443.

Coate, S. and S. Morris (1995). On the form of transfers to special interests. Journal of Political Economy 103, 1210-1235.

Cox, G. and M. McCubbins (1986). Electoral politics as a redistributive game. Journal of Politics 48, 370-389.

Cox, W. G. (2009). Swing voters, core voters, and distributive politics. In I. Shapiro, S. C. Stokes, E. J. Wood, and A. S. Kirshner (Eds.), Political representation, pp. 342-357. Cambridge, UK: Cambridge University Press.

Do, Q.-A., K.-T. Nguyen, and A. N. Tran (2016). One mandarin benefits the whole clan: Hometown favoritism in an authoritarian regime. forthcoming American Economic Journal: Applied Economics. 
Duflo, E. (2012). Women's empowerment and economic development. Journal of Economic Literature 50, 1051-1079.

Fiva, J. and A. Halse (2016). Local favoritism in at-large proportional representation systems. Journal of Public Economics 143, 15-26.

Franck, R. and I. Rainer (2012). Does the leader's ethnicity matter? Ethnic favoritism, education, and health in Sub-Saharan Africa. American Political Science Review 106(2), 294-325.

Hessami, Z. (2017). Accountability and incentives of appointed and elected public officials. Review of Economics and Statistics forthcoming.

Hodler, R. and P. Raschky (2014). Regional favoritism. Quarterly Journal of Economics 129(2), 995-1033.

Islam, N. (1995). Growth empirics: A panel data approach. Quarterly Journal of Economics 110(4), 1127-1170.

Johansson, E. (2003). Intergovernmental grants as a tactical instrument: empirical evidence from Swedish municipalities. Journal of Public Economics 87, 883-915.

Kramon, E. and D. Posner (2016). Ethnic favoritism in education in Kenya. Quarterly Journal of Political Science 11, 1-58.

Lindbeck, A. and J. Weibull (1987). Balanced budget redistribution as the outcome of political competition. Public Choice 52, 273-297. 
Lizzeri, A. and N. Persico (2001). The provision of public goods under alternative electoral incentives. American Economic Review 91(1), 225-239.

Milesi-Ferretti, G. M., R. Perotti, and M. Rostagno (2002). Electoral systems and public spending. Quarterly Journal of Economics 117(2), 609-657.

Murakozy, B. and A. Telegdy (2016). Political incentives and state subsidy allocation: Evidence from Hungarian municipalities. European Economic Review 89, 324-344.

Myerson, R. (1993). Incentives to cultivate favored minorities under alternative electoral systems. American Political Science Review 87, 856-869.

Pande, R. (2003). Can mandate political representation increase policy influence for disadvantaged minorities? Theory and evidence from India. American Economic Review 93(4), 1132-1151.

Rogoff, K. (1990). Equilibrium political business cycles. American Economic Review 80, 21-36.

Schnapp, K. U. (2006). Einfluss der Bundespolitik auf Landtagswahlen. Eine Analyse des Waehlerverhaltens auf Landesebene unter besonderer Beruecksichtigung der Bundespolitik. Research Project of the German Research Foundation.

Weingast, B., K. Shepsle, and C. Johnsen (1981). The political economy of costs and benefits: A neoclassical approach to distributive politics. Journal of Political Economy 89(4), 642-664.

Winkelmann, R. (2014). Unemployment and happiness. IZA World of Labor.

Wittman, D. (1983). Candidate motivation: A synthesis of alternative theories. American Political Science Review 72, 142-157. 


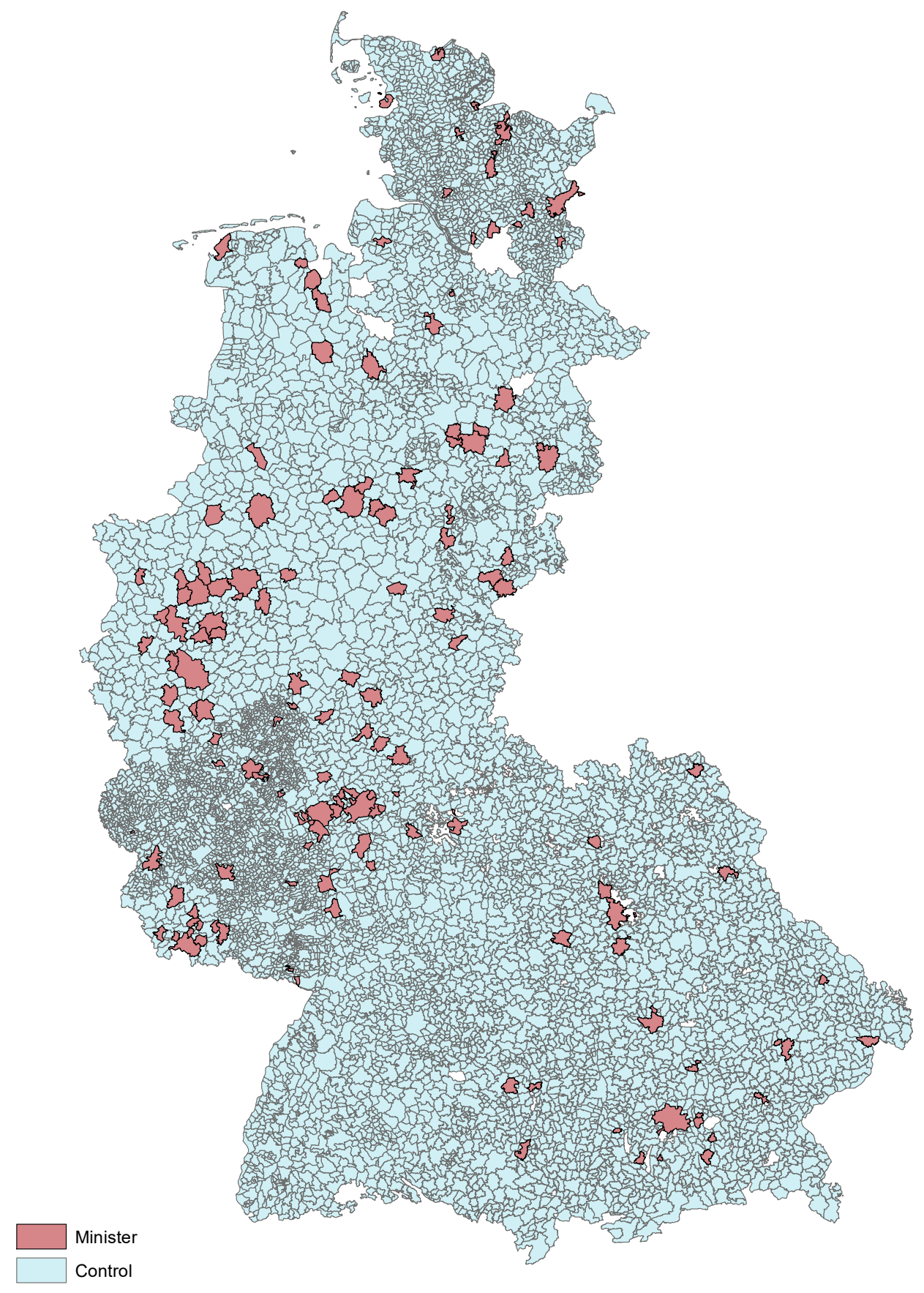

Figure 1: Minister and control municipalities 
Table 1: Summary statistics

\begin{tabular}{|c|c|c|c|c|c|}
\hline Variable & Count & Mean & SD & Min & Max \\
\hline \multicolumn{6}{|l|}{ Panel A: Ministers } \\
\hline Data on place of residence available & 367 & 0.812 & 0.391 & 0.000 & 1.000 \\
\hline Age of entry into office & 367 & 48.943 & 7.007 & 29.000 & 66.000 \\
\hline Age of exit from office & 367 & 55.406 & 7.375 & 34.000 & 69.000 \\
\hline Tenure & 367 & 8.390 & 5.440 & 1.000 & 42.000 \\
\hline Female & 367 & 0.294 & 0.456 & 0.000 & 1.000 \\
\hline $\mathrm{CDU}$ & 367 & 0.281 & 0.450 & 0.000 & 1.000 \\
\hline SPD & 367 & 0.431 & 0.496 & 0.000 & 1.000 \\
\hline FDP & 367 & 0.079 & 0.270 & 0.000 & 1.000 \\
\hline Green Party & 367 & 0.095 & 0.294 & 0.000 & 1.000 \\
\hline Other party & 367 & 0.114 & 0.319 & 0.000 & 1.000 \\
\hline Politics & 248 & 0.540 & 0.499 & 0.000 & 1.000 \\
\hline Public Administration & 248 & 0.052 & 0.223 & 0.000 & 1.000 \\
\hline Business & 248 & 0.214 & 0.411 & 0.000 & 1.000 \\
\hline Associations & 248 & 0.101 & 0.302 & 0.000 & 1.000 \\
\hline Academia & 248 & 0.036 & 0.187 & 0.000 & 1.000 \\
\hline Retired & 248 & 0.048 & 0.215 & 0.000 & 1.000 \\
\hline Identical place of residence and schooling & 297 & 0.239 & 0.427 & 0.000 & 1.000 \\
\hline \multicolumn{6}{|l|}{ Panel B: Municipalities } \\
\hline Employment growth & 169653 & 0.621 & 5.627 & -592.613 & 327.287 \\
\hline Minister & 169653 & 0.014 & 0.117 & 0.000 & 1.000 \\
\hline Minister CDU & 169653 & 0.007 & 0.083 & 0.000 & 1.000 \\
\hline Minister SPD & 169653 & 0.007 & 0.081 & 0.000 & 1.000 \\
\hline Minister FDP & 169653 & 0.002 & 0.043 & 0.000 & 1.000 \\
\hline Minister Green & 169653 & 0.001 & 0.033 & 0.000 & 1.000 \\
\hline Prime minister & 169653 & 0.002 & 0.047 & 0.000 & 1.000 \\
\hline Finance & 169653 & 0.002 & 0.050 & 0.000 & 1.000 \\
\hline Interior & 169653 & 0.003 & 0.051 & 0.000 & 1.000 \\
\hline Infrastructure & 169653 & 0.003 & 0.056 & 0.000 & 1.000 \\
\hline Social Policy & 169653 & 0.003 & 0.055 & 0.000 & 1.000 \\
\hline Culture \& Education & 169653 & 0.003 & 0.056 & 0.000 & 1.000 \\
\hline Environment & 169653 & 0.003 & 0.052 & 0.000 & 1.000 \\
\hline
\end{tabular}

a This table presents summary statistics on ministerial appointees and municipal characteristics. 
Table 2: Ministerial Appointments and Local Employment Growth: Baseline Results

\begin{tabular}{|c|c|c|c|}
\hline \multirow{3}{*}{ Minister } & (1) & (2) & (3) \\
\hline & $0.516^{* * *}$ & $0.434 * * *$ & $0.407 * * *$ \\
\hline & $(0.092)$ & $(0.090)$ & $(0.087)$ \\
\hline Municipality FE & Yes & Yes & Yes \\
\hline Year FE & Yes & Yes & Yes \\
\hline State-specific Trends & No & Yes & Yes \\
\hline State-specific year FE & No & No & Yes \\
\hline Observations & 167240 & 167240 & 167240 \\
\hline Municipalities & 8362 & 8362 & 8362 \\
\hline
\end{tabular}

a This table collects difference-in-differences regression results from the estimation of equation (2) evaluating the benefits of living in a minister municipality.

b The dependent variable is the growth rate of social-security covered employees in a municipality as defined in equation (1).

c All specifications include municipality fixed effects.

d Stars indicate significance levels at $10 \%(*), 5 \%(* *)$ and $1 \%(* * *)$.

e Heteroscedasticity robust standard errors in parentheses. 


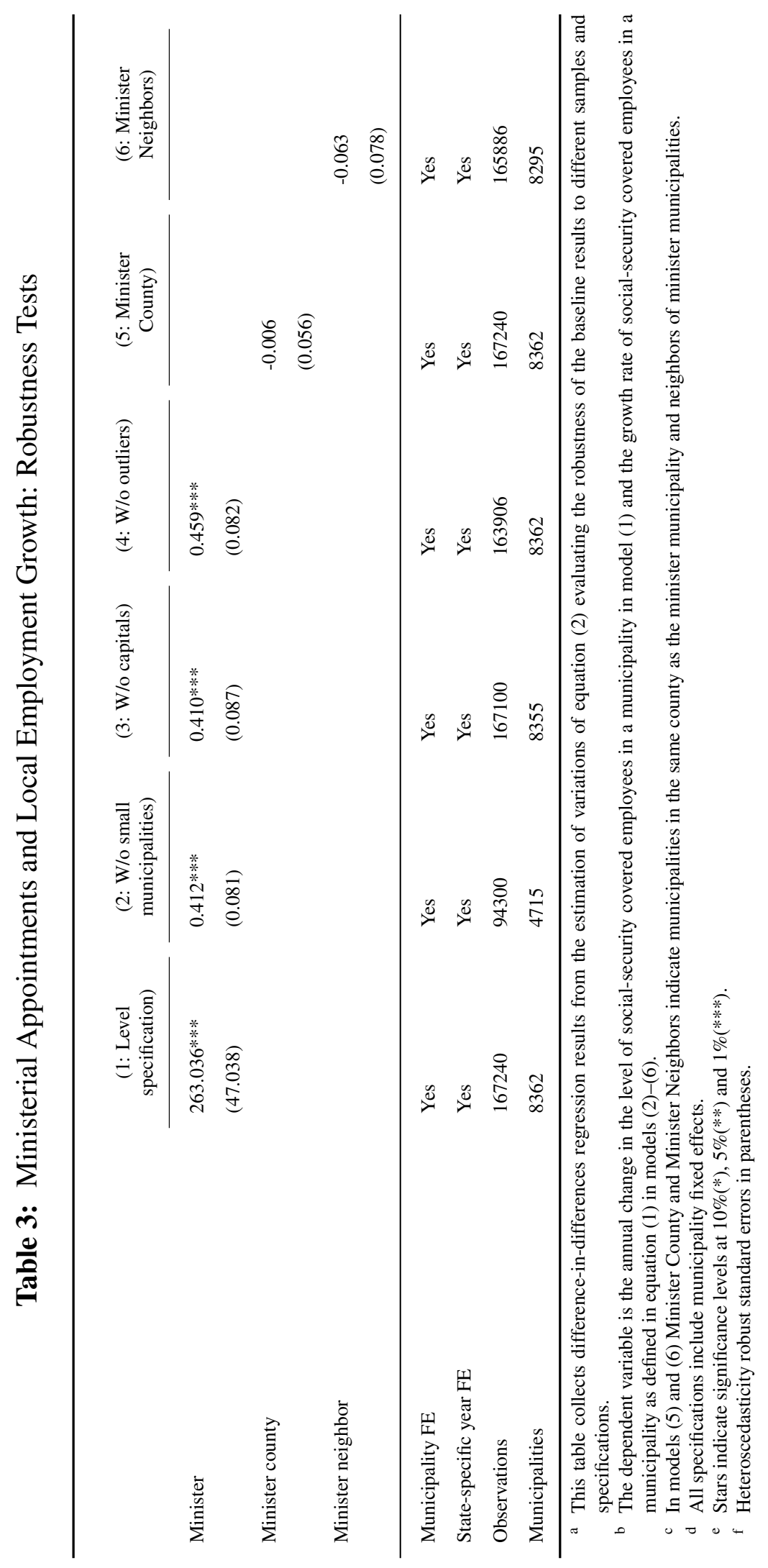


Table 4: Ministerial Appointment and Local Employment Growth: Minister Municipality and Close Neighbors

\begin{tabular}{|c|c|c|c|c|}
\hline \multirow{3}{*}{ Minister } & $(1: 50 \mathrm{~km})$ & $(2: 40 \mathrm{~km})$ & $(3: 30 \mathrm{~km})$ & $(4: 20 \mathrm{~km})$ \\
\hline & $0.246^{* *}$ & $0.348 * * *$ & $0.407 * * *$ & $0.408 * * *$ \\
\hline & $(0.099)$ & $(0.094)$ & $(0.089)$ & $(0.092)$ \\
\hline Municipality FE & Yes & Yes & Yes & Yes \\
\hline State-specific year FE & Yes & Yes & Yes & Yes \\
\hline Neighborhood FE & Yes & Yes & Yes & Yes \\
\hline Neighborhood-specific trends & Yes & Yes & Yes & Yes \\
\hline Observations & 161040 & 153840 & 134440 & 96000 \\
\hline Municipalities & 8052 & 7692 & 6722 & 4800 \\
\hline
\end{tabular}

a This table collects difference-in-differences regression results from the estimation of equation (2) evaluating the economic benefits of being the place of residence of a state minister. We only include non-minister municipalities whose centroids are at most either 50km (Model I), 40km (Model II), $30 \mathrm{~km}$ (Model III), or 20km (Model IV) away from the centroid of a minister municipality.

b The dependent variable is the growth rate of social-security covered employees in a municipality as defined in equation (1).

c Stars indicate significance levels at $10 \%(*), 5 \%(* *)$ and $1 \%(* * *)$.

d Heteroscedasticity robust standard errors in parentheses.

\section{Table 5: Ministerial Appointment and Local Employment Growth: Schooling in Town of Residence}

\begin{tabular}{|c|c|c|c|}
\hline & (1) & (2) & (3) \\
\hline \multirow[t]{2}{*}{ Minister $_{\text {Schooltown }}$} & $0.301 * *$ & & $0.468 * * *$ \\
\hline & $(0.135)$ & & $(0.124)$ \\
\hline \multirow[t]{2}{*}{ Minister $_{\text {Non-schooltown }}$} & & $0.319 * * *$ & $0.391 * * *$ \\
\hline & & $(0.094)$ & $(0.098)$ \\
\hline Municipality FE & Yes & Yes & Yes \\
\hline State-specific year FE & Yes & Yes & Yes \\
\hline Observations & 167240 & 167240 & 167240 \\
\hline Municipalities & 8362 & 8362 & 8362 \\
\hline
\end{tabular}

a This table collects difference-in-differences regression results from the estimation of variations of equation (2) evaluating the robustness of the baseline results to measurement error.

b The dependent variable is the growth rate of social-security covered employees in a municipality as defined in equation (1).

c The dummies Minister ${ }_{S c h o o l t o w n}$ and Minister $_{\text {Non-schooltown }}$ indicate ministers that reside in the same municipality in which they went to school and ministers that do not or for which we have no information on the place of schooling.

d All specifications include municipality fixed effects.

e Stars indicate significance levels at $10 \%(*), 5 \%(* *)$ and $1 \%(* * *)$.

$\mathrm{f}$ Heteroscedasticity robust standard errors in parentheses. 


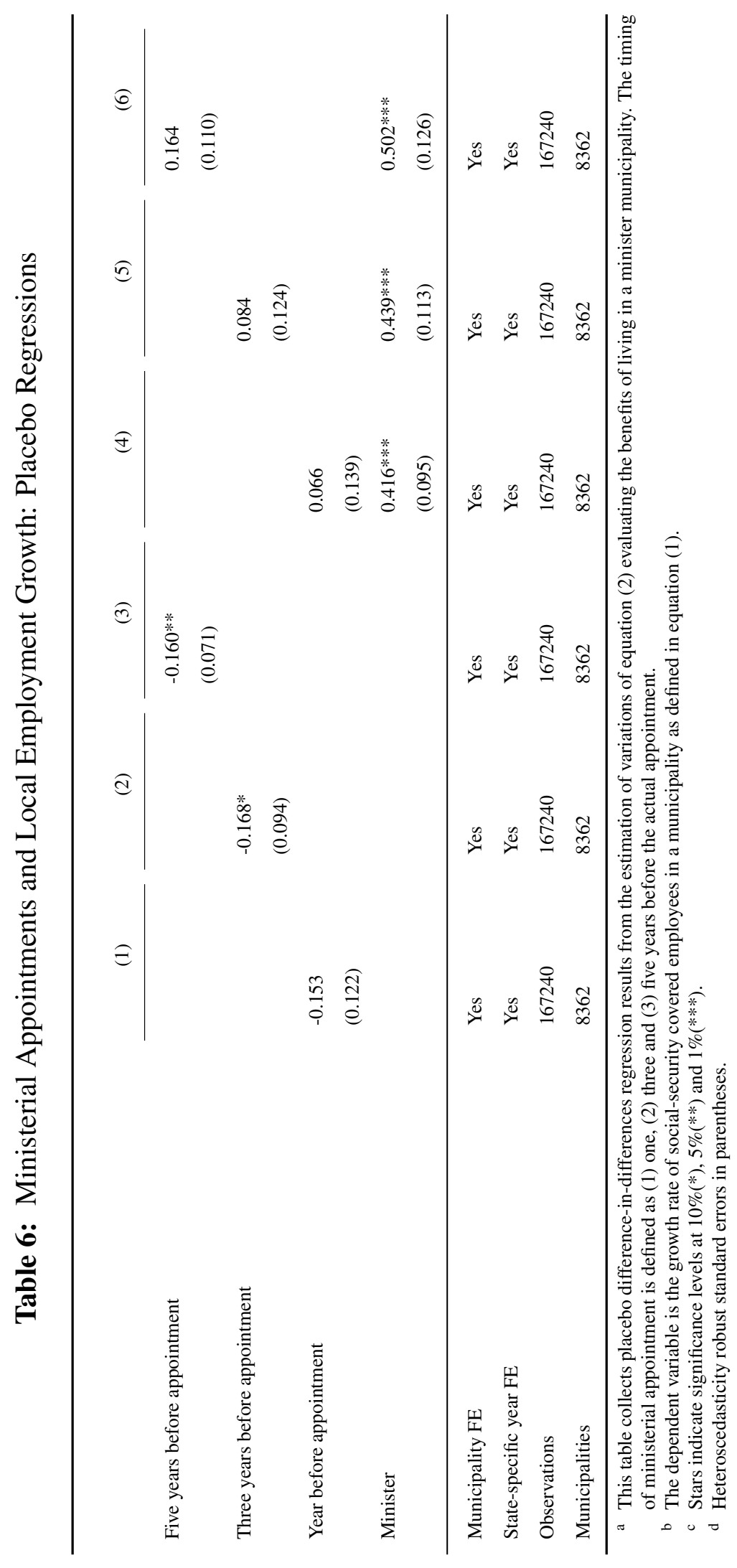




\section{Table 7: Ministerial Appointment and Local Employment Growth: Timing}

\begin{tabular}{|c|c|c|c|}
\hline & (1) & (2) & (3) \\
\hline \multirow[t]{2}{*}{ Minister, in office } & $0.274 * * *$ & & \\
\hline & $(0.091)$ & & \\
\hline \multirow[t]{2}{*}{ Up to five years after appointment } & & $0.319 * * *$ & \\
\hline & & $(0.101)$ & \\
\hline \multirow[t]{2}{*}{ Five years after appointment onwards } & & $0.699 * * *$ & \\
\hline & & $(0.133)$ & \\
\hline \multirow[t]{2}{*}{ Up to three years after appointment } & & & $0.318^{* * *}$ \\
\hline & & & $(0.107)$ \\
\hline \multirow[t]{2}{*}{ Fourth and fifth years after appointment } & & & $0.334 * * *$ \\
\hline & & & $(0.125)$ \\
\hline \multirow[t]{2}{*}{ Six to ten years after appointment } & & & $0.360 * *$ \\
\hline & & & $(0.142)$ \\
\hline \multirow[t]{2}{*}{ Ten years after appointment until dismissal } & & & $0.793 * * *$ \\
\hline & & & $(0.159)$ \\
\hline \multirow[t]{2}{*}{ After dismissal } & $0.708 * * *$ & & $0.825 * * *$ \\
\hline & $(0.122)$ & & $(0.151)$ \\
\hline Municipality FE & Yes & Yes & Yes \\
\hline State-specific year FE & Yes & Yes & Yes \\
\hline Observations & 167240 & 167240 & 167240 \\
\hline Municipalities & 8362 & 8362 & 8362 \\
\hline
\end{tabular}

a This table collects difference-in-differences regression results from the estimation of variations of equation (2) evaluating the benefits of living in a minister municipality during and after the tenure of state ministers.

b The dependent variable is the growth rate of social-security covered employees in a municipality as defined in equation (1).

c All specifications include municipality fixed effects.

d Stars indicate significance levels at 10\%(*), 5\%(**) and $1 \%(* * *)$.

e Heteroscedasticity robust standard errors in parentheses. 


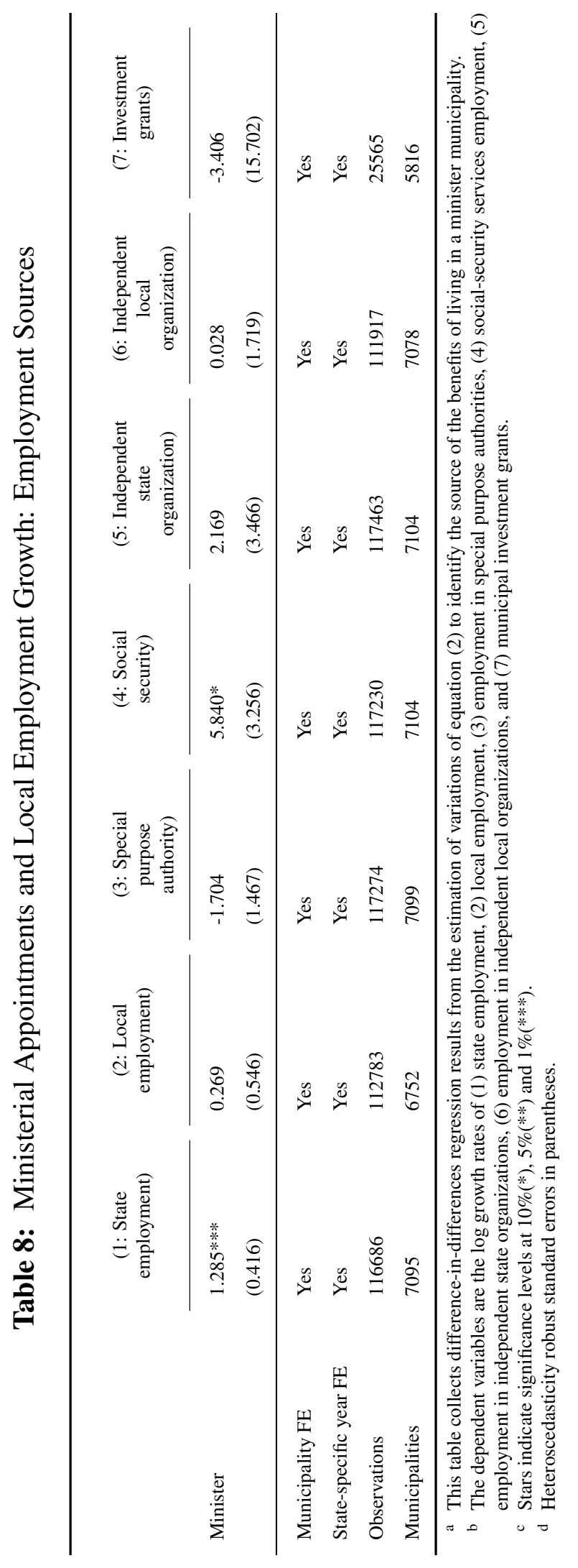


Table 9: Ministerial Appointments and Local Employment Growth: Employment According to Workplace

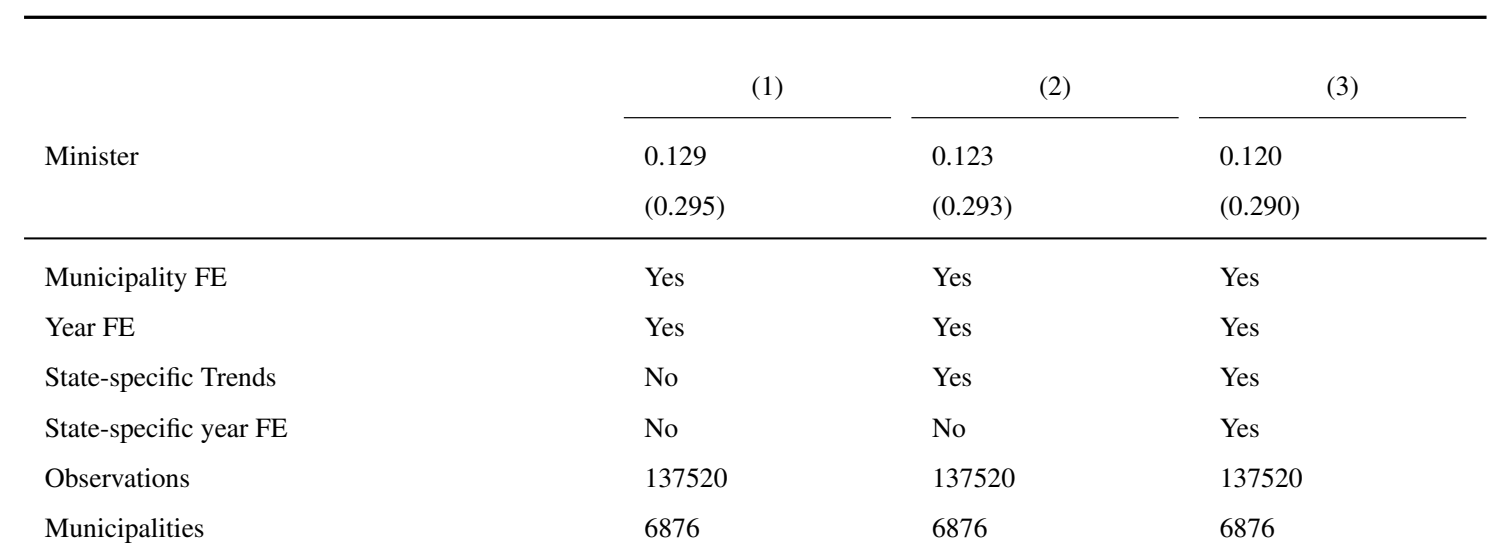

a This table collects difference-in-differences regression results from the estimation of equation (2) evaluating the benefits of living in a minister municipality.

b The dependent variable is the growth rate of social-security covered employees in a municipality as defined in Equation (1).

c Stars indicate significance levels at $10 \%(*), 5 \%(* *)$ and $1 \%(* * *)$.

d Heteroscedasticity robust standard errors in parentheses. 


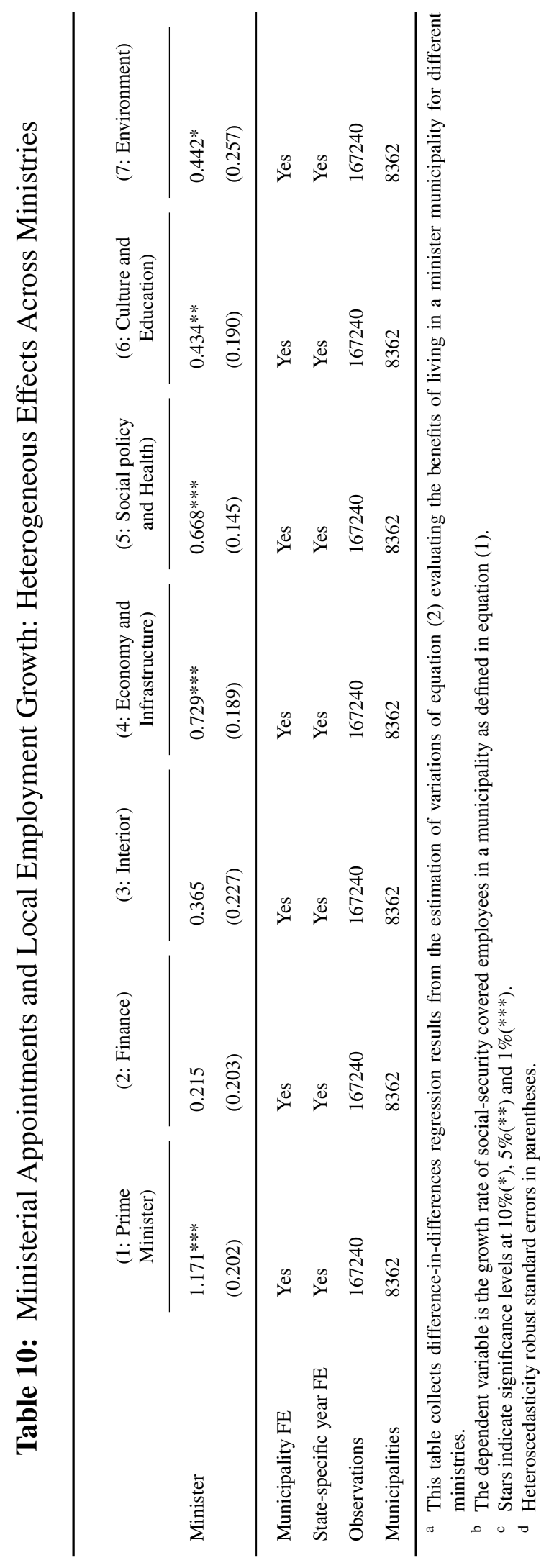


Table 11: Ministerial Appointments and Local Employment Growth: Heterogeneous Effects Across Career Paths

\begin{tabular}{|c|c|c|c|c|c|}
\hline & (1: Politics) & $\begin{array}{c}\text { (2: Public } \\
\text { Administration) }\end{array}$ & (3: Business) & (4: Association) & (5: Academia) \\
\hline \multirow[t]{2}{*}{ Minister } & $0.333 * * *$ & $0.419 * * *$ & $0.387 * * *$ & $0.418 * * *$ & $0.423 * * *$ \\
\hline & $(0.090)$ & $(0.086)$ & $(0.085)$ & $(0.087)$ & $(0.086)$ \\
\hline \multirow[t]{2}{*}{ Post-office employment } & $0.536^{* * *}$ & $0.670^{* * *}$ & $0.645^{* *}$ & 0.245 & 0.146 \\
\hline & $(0.162)$ & $(0.210)$ & $(0.263)$ & $(0.235)$ & $(0.905)$ \\
\hline Municipality FE & Yes & Yes & Yes & Yes & Yes \\
\hline State-specific year FE & Yes & Yes & Yes & Yes & Yes \\
\hline Observations & 169645 & 169645 & 169645 & 169645 & 169645 \\
\hline Municipalities & 8552 & 8552 & 8552 & 8552 & 8552 \\
\hline
\end{tabular}

\footnotetext{
a This table collects difference-in-differences regression results from the estimation of variations of equation (2) evaluating the benefits of living in a minister municipality for the different career paths ministers follow after holding office.

b The dependent variable is the growth rate of social-security covered employees in a municipality as defined in equation (1).

c Stars indicate significance levels at $10 \%(*), 5 \%(* *)$ and $1 \%(* * *)$.

d Heteroscedasticity robust standard errors in parentheses.
} 
Table 12: Ministerial Appointments and Local Employment Growth: Heterogeneous Effects Across Parties

\begin{tabular}{|c|c|c|c|c|}
\hline \multirow{3}{*}{ Minister } & (1: CDU) & (2: SPD) & (3: FDP) & (4: Greens) \\
\hline & $0.427 * * *$ & $0.401 * *$ & $0.509 * * *$ & $0.674 * *$ \\
\hline & $(0.106)$ & $(0.175)$ & $(0.196)$ & $(0.284)$ \\
\hline Municipality FE & Yes & Yes & Yes & Yes \\
\hline State-specific year FE & Yes & Yes & Yes & Yes \\
\hline Observations & 167240 & 167240 & 167240 & 167240 \\
\hline Municipalities & 8362 & 8362 & 8362 & 8362 \\
\hline
\end{tabular}

a This table collects difference-in-differences regression results from the estimation of equation (2) evaluating the benefits of living in a minister municipality for different parties.

b The dependent variable is the growth rate of social-security covered employees in a municipality as defined in equation (1).

c Stars indicate significance levels at $10 \%(*), 5 \%(* *)$ and $1 \%(* * *)$.

d Heteroscedasticity robust standard errors in parentheses.

Table 13: Ministerial Appointments and Local Employment Growth: Heterogeneous Effects Across Gender

\begin{tabular}{|c|c|c|c|}
\hline & (1) & (2) & (3) \\
\hline \multirow{2}{*}{ Male } & $0.466^{* * * *}$ & & $0.458 * * *$ \\
\hline & $(0.091)$ & & $(0.090)$ \\
\hline \multirow[t]{2}{*}{ Female } & & $0.417 * *$ & $0.398 * *$ \\
\hline & & $(0.174)$ & $(0.172)$ \\
\hline Municipality FE & Yes & Yes & Yes \\
\hline State-specific year FE & Yes & Yes & Yes \\
\hline Observations & 167240 & 167240 & 167240 \\
\hline Municipalities & 8362 & 8362 & 8362 \\
\hline
\end{tabular}

a This table collects difference-in-differences regression results from the estimation of equation (2) evaluating the benefits of living in a minister municipality depending on the gender of the minister.

b The dependent variable is the growth rate of social-security covered employees in a municipality as defined in equation (1).

c Stars indicate significance levels at $10 \%(*), 5 \%(* *)$ and $1 \%(* * *)$.

d Heteroscedasticity robust standard errors in parentheses. 